\title{
Initial Psychological Response of Various Population Groups to COVID-19 Pandemic: A Cross Sectional Study
} ${ }^{1}$ Shahzaib Ahmad, ${ }^{1}$ Muhammad Abubakar Shahid Chishti, ${ }^{2}$ Usman Hotiana,

${ }^{3}$ Tania A. Shakoori

${ }^{I}$ Department of Surgery, King Edward Medical University, Lahore

${ }^{2}$ Department of Psychiatry, Rashid Latif Medical College, Lahore

${ }^{3}$ Institute of Molecular Biology and Biotechnology, University of Lahore

\begin{abstract}
Introduction: The corona virus pandemic has brought with it psychological problems like anxiety, stress, and depression. Research studies are urgently required to generate data that would help formulate strategies to manage the ensuing psychiatric and psychological maladies at societal level.

Aims \& Objectives: The aim of our study is to better comprehend the initial psychological response of society to COVID-19 outbreak though a survey.

Place and duration of study: This cross-sectional study was conducted in King Edward Medical University, Lahore from April 2020 to October 2020.

Material \& Methods: An online questionnaire comprising of 20 items including the Zung self-rating Anxiety Scale (SAS) was disseminated to three fifty (350) participants. Two hundred and seventy-one $(n=271)$ responses were received. Collected data was entered and analyzed using the SPSS software version 20. Categorical variables were presented as frequencies and percentages. Relationships between categorical variables were tested by Chi square test. Regression analysis was conducted to investigate the effect of various variables on total stress score. A p-value of $<0.05$ was considered significant.

Results: It was revealed that $85.2 \%$ of the respondents reported minimal psychological impact, $14.8 \%$ had mild to moderate anxiety levels and $0.4 \%$ reported marked to severe anxiety. The impact was 2.5 times greater in subjects belonging to lower socioeconomic status $(\mathrm{p}=0.02)$.

Conclusion: Population belonging to lower socioeconomic class is more vulnerable to be impacted by psychological disturbances due to the pandemic owing to economic losses that are magnified in the population with fragile earning sources.
\end{abstract}

Key words: COVID-19, pandemic, anxiety, psychological stress, socioeconomic status, Zhang self-rating anxiety scale.

\section{INTRODUCTION}

$\mathrm{V}$ arious pandemics with high morbidity and mortality have affected millions of people all around the world throughout human history. ${ }^{1,2}$ The first viral pandemic was reported in 1918. It was named as Spanish flu, and the causative virus was the H1N1 influenza virus. It affected 500 million people around the world, and almost 40 million people died worldwide from 1918-1919. ${ }^{3}$ Similarly the second H1N1 swine flu pandemic occurred during 2009210 affecting 6.8 billion people worldwide and caused around 5 million deaths. ${ }^{4}$

The recent pandemic of COVID-19 is another flu pandemic that started in the city of Wuhan, China, in December 2019.5 This disease outbreak was declared as a pandemic by WHO on 30 January 2020 and has affected almost every country of the world. ${ }^{6}$ Some countries like China, Japan, Iraq,
South Korea, and some European countries have managed to contain the virus to some extent after a lot of efforts. ${ }^{6}$ It is similar to common flu but highly contagious. $^{7}$ In February 2020, covid-19 was first reported in Pakistan in two patients who had recently returned from Iran. ${ }^{8}$ By April 2020, the Ministry of Health, government of Pakistan, confirmed a total of 3277 positive cases including 18 critical patients and 50 mortalities. ${ }^{9}$ Till date (24-21) there have been 537,477 diagnosed cases with 11,450 reported deaths. ${ }^{10}$

The extensive coverage and repetition of reports in the media, might be contributing to the unspecific anxiety, depression and COVID-specific fear. ${ }^{11}$ In addition the myths and conspiracy theories regarding COVID-19, spread by social media platforms, add to the confusion and psychological stress of the public. ${ }^{12,13}$ Several studies have shown that excessive mainstream and social media consumption is associated with increased level of 
COVID-19 associated fear and panic in the society. ${ }^{11,14,15}$

There is limited data on COVID-19 associated anxiety and stress response especially in the South East Asian region. The excessive psychological response to a pandemic disease can result in avoidance, functional impairment, and clinically significant distress among people. ${ }^{16}$ It can lead to exaggerated safety behaviors like repeated hand washing and seeking reassurance from doctors repetitively, which further impairs functioning. Mass psychogenic illness can result from these highly publicized disease outbreaks in which healthy individuals become over sensitive to their benign bodily signs and sensations. They suspect themselves as infected, further engaging in extreme safety behaviors. Such individuals utilize more medical resources, including medications and other protective equipment, causing further load on the economy of the affected country. ${ }^{17}$

The stress and anxiety response to the corona pandemic may vary in different strata of the local population. The current study aimed to investigate the psychological responses (stress and anxiety) of the masses in Pakistan about the ongoing COVID19 pandemic and find out how it is affecting the functionality of individuals belonging to different socio economic and demographic strata. Understanding such responses will be helpful in public health campaigns directed at stimulating people to take necessary precautions against corona virus infection without psychological stress.

\section{MATERIAL AND METHODS}

A cross sectional descriptive study was designed. Ethical permission was taken from the Institutional Review Board. Three hundred fifty questionnaire (350) requests were sent by email to medical doctors and students of Lahore. Two hundred and seventyone $(n=271)$ responses were received. The online questionnaire was composed of 3 parts. The questions were prepared after thorough review of literature and were sent to 3 independent psychiatrists for their expert opinion.

\section{Statistical analysis:}

The results were recorded as frequencies and percentages. Logistic regression analysis was applied with anxiety levels (mild, moderate or severe versus normal) as dependent variable and age, gender, monthly income and being a medical professional as dependent variables. Significance was set at 'p' less than 0.05 .

\section{RESULTS}

The respondents included both men and women between eleven (11) and sixty (60) years of age. The majority was either medical students or related to the medical profession. The detailed demographic characteristics are shown in Table-1.

The psychological impact of COVID-19 pandemic, measured using the Zung self-rating Anxiety Scale (SAS) scale, revealed a sample mean score of 35.92 $(\mathrm{SD}=8.36)$. Of all the respondents, $239(85.2 \%)$ reported minimal psychological impact (score $<45$ ) and they were labeled normal according to Zhang self-rating anxiety scale; $39(14.4 \%)$ had mild to moderate anxiety levels (scores 45-59); and 1 respondent $(0.4 \%)$ reported marked to severe anxiety (scores 60-74).

We further explored if any of the demographic characteristics put the subjects at a greater risk of anxiety than others. It was revealed that low income subjects were 2.5 times more likely to be stressed than subjects with higher income $(\mathrm{p}=0.021)$. None of the other demographic factors were significant risk factors for psychological stress in our cohort (Table-3).

\begin{tabular}{|l|c|c|}
\hline Factor & $\begin{array}{c}\text { Total Sample } \\
(\mathbf{n}=\mathbf{2 7 1})\end{array}$ & $\begin{array}{c}\text { Percent } \\
\text { Sample }\end{array}$ \\
\hline Gender & 106 & 39.1 \\
\hline Male & 165 & 60.9 \\
\hline Female & \multicolumn{2}{|l|}{} \\
\hline Age Range (in years) & 97 & 35.8 \\
\hline $11-20$ & 164 & 60.5 \\
\hline $21-30$ & 9 & 3.3 \\
\hline $31-40$ & 1 & .4 \\
\hline $51-60$ & 238 & 87.8 \\
\hline Monthly Income (in Pakistani Rupees) \\
\hline I Don't Earn & 11 & 4.1 \\
\hline Less than 20,000 & 7 & 2.6 \\
\hline 20,000-40,000 & 13 & 4.8 \\
\hline Greater than 40,000 & 166 & 61.3 \\
\hline Socioeconomic Status (based on self-perception) \\
\hline Middle Class & 15 & 5.5 \\
\hline Lower Middle Class & 88 & 32.5 \\
\hline Upper Middle Class & 2 & .7 \\
\hline Low class & \multicolumn{2}{|l|}{} \\
\hline Profession & 69 & 25.5 \\
\hline Medical Professional & 2 & .7 \\
\hline Government Employee & 9 & 3.3 \\
\hline Private Employee & 7 & 2.6 \\
\hline Unemployed & 2 & .7 \\
\hline Business & 179 & 66.1 \\
\hline Student & 3 & 1.1 \\
\hline Others & \\
\hline
\end{tabular}

Table-1: Demographic characteristics of the respondents 


\begin{tabular}{|c|c|c|}
\hline \# & Questions & Responses \\
\hline & $\begin{array}{l}\text { Do you think it is necessary to } \\
\text { get mental health tips if one } \\
\text { panics in the pandemic } \\
\text { situation? }\end{array}$ & $\begin{array}{l}\text { Yes: } 232(86 \%) \\
\text { No: } 8(3 \%) \\
\text { Maybe: } 30(11.1 \%)\end{array}$ \\
\hline 2 & $\begin{array}{l}\text { From the last week, how often } \\
\text { you avoid ordering food online? }\end{array}$ & $\begin{array}{l}\text { Many times: } 167(61.6 \%) \\
\text { Sometimes: } 37(13.7 \%) \\
\text { Never: } 66(24.4 \%)\end{array}$ \\
\hline 3 & $\begin{array}{l}\text { From the last week, how often } \\
\text { you feel the urge to go outside? }\end{array}$ & $\begin{array}{l}\text { Frequently: } 84(31.0 \%) \\
\text { Less frequently: } 134(49.4 \%) \\
\text { Never: } 52(19.2 \%) \\
\end{array}$ \\
\hline 4 & $\begin{array}{l}\text { From the last week, how often } \\
\text { you avoid large meetings and } \\
\text { gatherings? } *\end{array}$ & $\begin{array}{l}\text { Many times: } 105(37.8 \%) \\
\text { Sometimes: } 20(7.4 \%) \\
\text { Never: } 7(2.6 \%) \\
\text { Always: } 138(50.9 \%)\end{array}$ \\
\hline 5 & $\begin{array}{l}\text { From the last week, how often } \\
\text { you avoid social contact? }\end{array}$ & $\begin{array}{l}\text { Many times: } 219(80.8 \%) \\
\text { Sometimes: } 44(16.2 \%) \\
\text { Never: } 7(2.6 \%) \\
\end{array}$ \\
\hline 6 & Feel helpless due to COVID-19? & $\begin{array}{l}\text { Yes: } 113(41.7 \%) \\
\text { No: } 156(57.9 \%)\end{array}$ \\
\hline 7 & $\begin{array}{l}\text { Do you think travelling } \\
\text { across/within the country is safe } \\
\text { during these times? } *\end{array}$ & $\begin{array}{l}\text { Yes: } 14(5.3 \%) \\
\text { No: } 240(88.6 \%) \\
\text { Maybe: } 16(5.9 \%) \\
\end{array}$ \\
\hline 8 & $\begin{array}{l}\text { Do you think social distancing } \\
\text { is essential to stop the corona } \\
\text { Virus spread? }\end{array}$ & $\begin{array}{l}\text { Yes: } 250(92.3 \%) \\
\text { No: } 5(1.8 \%) \\
\text { Maybe: } 15(5.5 \%) \\
\end{array}$ \\
\hline 9 & $\begin{array}{l}\text { How much do you feel affected } \\
\text { by the posts on social media } \\
\text { about corona Virus Infection? }\end{array}$ & \begin{tabular}{|l|} 
To a large extent: $59(21.8 \%)$ \\
To some extent: $156(57.6 \%)$ \\
Not affected at all:55(20.3\%)
\end{tabular} \\
\hline
\end{tabular}

Table-2: A summary of responses of the respondents

\begin{tabular}{|l|c|c|}
\hline Risk Factors & P value & Odds ratio \\
\hline $\begin{array}{l}\text { Low monthly income } \\
\text { (less than 10,000 PKR) }\end{array}$ & $0.02^{*}$ & $2.5^{*}$ \\
\hline Gender & 0.75 & 0.92 \\
\hline Medical professionals & 0.99 & 0.99 \\
\hline Age & 0.11 & 1.52 \\
\hline
\end{tabular}

Table-3: Risk Factors for COVID related Psychological Stress

\section{DISCUSSION}

The most interesting finding of our study is that $85 \%$ participants thought they could use expert recommendation, only $3 \%$ denied such help. This is similar to result reported from Wuhan where $50.4 \%$ sought online help, $36.3 \%$ referred to books $(36.3 \%)$ and $17.5 \%$ took counseling. ${ }^{18}$ Exploring the factors that enhance COVID impact included corona related social posts on social media to a large effect in $21.8 \%$, to some extent in $57.8 \%$ and no effect in $20.3 \%$. This needs to be explored what exactly makes some more vulnerable and some more resilient in future studies. In Spanish sample, being a young female with negative self-perceptions, more time exposed to COVID, more contact with relatives and higher expressed emotions were associated with increased burden. ${ }^{19}$ In our study pandemic influenced $61.6 \%$ people to not order food frequently while $24.4 \%$ avoided food delivery altogether (Table-2). In US $25.6 \%$ and in UK $29.6 \%$ people thought that only Chinese restaurants should be avoided according to an online perceptions study. ${ }^{20}$ Meanwhile in Italy, a lifestyle change in form of increased worry about weight gain in $48.6 \%$, quitting smoking $(3.3 \%$ ) and turning to organic food $(15 \%)$ was seen. ${ }^{21}$ In the current research, $49.4 \%$ participants reported a reduced urge to go outdoors while $31.0 \%$ felt the urge frequently and $19.2 \%$ never felt the urge. The pandemic anxiety made $37.8 \%$ participants avoid large gatherings on many occasions, while $50.9 \%$ always avoided. It was only $2.6 \%$ were the ones which did not avoid at all. This small non avoiding population could be interesting to study further. One of the explanations came from a study of personality traits. It was found people who were low on agreeableness and high of dark triad traits like Machiavellianism, psychopathy factor 1 and narcissistic rivalry were least likely to follow guidelines. ${ }^{22}$

We further found that $41.7 \%$ participants felt helpless during COVID while $57.9 \%$ did not feel this way. What makes one feels helpless or not could be a future inquiry. It has been found for example, that adapting recommendations in form of avoidance behavior is associated with trust in government, perceived effect of effectiveness and ability to follow recommendations. ${ }^{23}$

It also came to light that $88.6 \%$ of the respondents thought it unsafe to travel both abroad and locally while 5.3\% thought it was safe. Furthermore 92.3\% of the subjects thought that social distancing was an essential to stop the corona virus spread, and only $1.8 \%$ thought it was not essential. When we compare these percentages with a related Iranian medical study, a similar pattern is revealed. In the study, $94.47 \%$ were practicing preventive behaviors and $86.96 \%$ held correct answers about COVID facts. ${ }^{24}$

In our study normal range of anxiety was experienced by $85.2 \%$ participants while mild to moderate level by $14.4 \%$ and marked to severe in $0.4 \%$ of the sample. This means broad based public interventions could be more helpful.

In the future more customized perceptions and behaviors amongst different specialties can be checked. We can also include the tangible change in the actual behavior in response to a particular perception. We can further include perceptions in participants with a history or active psychiatric illness as well. In this study we only documented presence of a study. 


\section{CONCLUSION}

The current study shows that most subjects rated their psychological impact as mild-to-moderate. The psychological stress was 2.5 more prevalent in subjects from lower socioeconomic status. Our study adds to the ever emerging data on psychological impact of the corona pandemic and can be useful for public health officials to formulate the various interventions for improvement of mental health during COVID-19 outbreak.

\section{REFERENCES}

1. Huremović D. Brief history of pandemics (pandemics throughout history). Psychiatry of pandemics: Springer; 2019. p. 7-35.

2. Habicht ME, Pate FD, Varotto E, Galassi FM. Epidemics and pandemics in the history of humankind and how governments dealt with them $\mathrm{A}$ review from the Bronze Age to the Early Modern Age. Rivista Trimestrale Di Scienza Dell'Amministrazione. 2020;2.

3. More AF, Loveluck CP, Clifford H, Handley MJ, Korotkikh EV, Kurbatov AV, et al. The impact of a six-year climate anomaly on the "Spanish flu" pandemic and WWI. GeoHealth. 2020; 4(9):e2020GH000277.

4. Gavrilova NS, Gavrilov LA. Patterns of mortality during pandemic: An example of Spanish flu pandemic of 1918. Population and economics. 2020; 4(2):56.

5. Eastin C, Eastin T. Clinical Characteristics of Coronavirus Disease 2019 in China: Guan W, Ni Z, $\mathrm{Hu}$ Y, et al. N Engl J Med. 2020 Feb 28 [Online ahead of print. The Journal of Emergency Medicine. 2020; 58(4):711.

6. Trilla A. One world, one health: The novel coronavirus COVID-19 epidemic. Medicina clinica (English ed). 2020; 154(5):175.

7. Wu Y-C, Chen C-S, Chan Y-J. Overview of the 2019 novel coronavirus $(2019-\mathrm{nCoV})$ : the pathogen of severe specific contagious pneumonia (SSCP). J Chin Med Assoc. 2020; 83(3):217-20.

8. Badshah SL, Ullah A, Badshah SH, Ahmad I. Spread of Novel coronavirus by returning pilgrims from Iran to Pakistan. Journal of Travel Medicine. 2020; 27(3):taaa044.

9. Waris A, Khan AU, Ali M, Ali A, Baset A. COVID19 outbreak: current scenario of Pakistan. New Microbes and New Infections. 2020:100681.

10. Pakistan Go. COVID-19 Dashboard. Official Portal, Governement of Pakistan: Government of Pakistan; [cited 202127 January]. Available from: https://covid.gov.pk/.

11. Bendau A, Petzold MB, Pyrkosch L, Maricic LM, Betzler F, Rogoll J, et al. Associations between COVID-19 related media consumption and symptoms of anxiety, depression and COVID-19 related fear in the general population in Germany. European archives of psychiatry and clinical neuroscience. 2020: 1-9.

12. Sahoo S, Padhy SK, Ipsita J, Mehra A, Grover S. Demystifying the myths about COVID-19 infection and its societal importance. Asian journal of psychiatry. 2020.

13. Lin D, Friedman DB, Qiao S, Tam CC, Li X, Li X. Information uncertainty: a correlate for acute stress disorder during the COVID-19 outbreak in China. BMC Public Health. 2020; 20(1):1-9.

14. Nekliudov NA, Blyuss O, Cheung KY, Petrou L, Genuneit J, Sushentsev N, et al. Excessive media consumption about COVID-19 is associated with increased state anxiety: outcomes of a large online survey in Russia. Journal of medical Internet research. 2020; 22(9):e20955.

15. Rommer D, Majerova J, Machova V. Repeated COVID-19 pandemic-related media consumption: Minimizing sharing of nonsensical misinformation through health literacy and critical thinking. Linguistic and Philosophical Investigations. 2020; 19:107-13.

16. Asmundson GJ, Taylor S. How health anxiety influences responses to viral outbreaks like COVID19: What all decision-makers, health authorities, and health care professionals need to know. Journal of anxiety disorders. 2020; 71:102211.

17. Chatterjee SS, Vora M, Malathesh BC, Bhattacharyaa R. Worried well and Covid-19: Reemergence of an old quandary. Asian journal of psychiatry. 2020.

18. Kang L, Ma S, Chen M, Yang J, Wang Y, Li R, et al. Impact on mental health and perceptions of psychological care among medical and nursing staff in Wuhan during the 2019 novel coronavirus disease outbreak: A cross-sectional study. Brain, behavior, and immunity. 2020; 87:11-7.

19. Losada-Baltar A, Jiménez-Gonzalo L, GallegoAlberto L, Pedroso-Chaparro MdS, Fernandes-Pires J, Márquez-González M. "We Are Staying at Home." Association of self-perceptions of aging, personal and family resources, and loneliness with psychological distress during the lock-down period of COVID-19. The Journals of Gerontology: Series B. 2021; 76(2):e10-e6.

20. Geldsetzer P. Use of rapid online surveys to assess people's perceptions during infectious disease outbreaks: a cross-sectional survey on COVID-19. Journal of medical Internet research. 2020; 22(4):e18790.

21. Di Renzo L, Gualtieri P, Pivari F, Soldati L, Attinà A, Cinelli G, et al. Eating habits and lifestyle changes during COVID-19 lockdown:an Italian survey.Journal of translational medicine.2020;18:1-15

22. Zajenkowski M, Jonason PK, Leniarska M, Kozakiewicz Z. Who complies with the restrictions to reduce the spread of COVID-19?: Personality and perceptions of the COVID-19 situation. Personality and Individual Differences. 2020; 166:110199. 
23. Seale H, Heywood AE, Leask J, Sheel M, Thomas S, Durrheim DN, et al. COVID-19 is rapidly changing: Examining public perceptions and behaviors in response to this evolving pandemic. PloS one. 2020; 15(6):e0235112.

24. Taghrir MH, Borazjani R, Shiraly R. COVID-19 and Iranian medical students; a survey on their relatedknowledge, preventive behaviors and risk perception. Archives of Iranian medicine. 2020; 23(4):249-54.

\section{The Authors:}

Shahzaib Ahmad

Final Year Medical Student,

King Edward Medical University, Lahore.

Muhammad Abubakar Shahid Chishti

Final Year Medical Student,

Department of Surgery,

King Edward Medical University, Lahore.
Prof. Usman Hotiana

Head, Department of Psychiatry,

Rashid Latif Medical College, Lahore.

Dr. Tania A. Shakoori

Associate Professor,

Department of Physiology,

Institute of Molecular Biology and Biotechnology, University of Lahore, Lahore

\section{Corresponding Author:}

Dr. Tania A. Shakoori

Associate Professor,

Department of Physiology,

Institute of Molecular Biology and Biotechnology,

University of Lahore, Lahore.

E-mail: drtaniashakoori@yahoo.com 